inOedia $\quad \begin{aligned} & \text { InMedia } \\ & \text { The French Journal of Media Studies }\end{aligned}$

5 | 2014

Media and Diversity

\title{
The Concept of Culture in Media Studies: A Critical Review of Academic Literature
}

Mélodine Sommier

\section{(2) OpenEdition \\ 12 Journals}

\section{Electronic version}

URL: http://journals.openedition.org/inmedia/768

DOI: 10.4000/inmedia.768

ISSN: 2259-4728

\section{Publisher}

Center for Research on the English-Speaking World (CREW)

\section{Electronic reference}

Mélodine Sommier, «The Concept of Culture in Media Studies: A Critical Review of Academic Literature », InMedia [Online], 5 | 2014, Online since 17 October 2014, connection on 10 December 2020. URL : http://journals.openedition.org/inmedia/768 ; DOI : https://doi.org/10.4000/inmedia.768

This text was automatically generated on 10 December 2020 .

(C) InMedia 


\title{
The Concept of Culture in Media Studies: A Critical Review of Academic Literature
}

\author{
Mélodine Sommier
}

1 Recent directions in the field of media studies have turned culture into a significant object of study. Strong emphasis has been put on representations of minorities in media ${ }^{1}$ and their potential biases, ${ }^{2}$ minority-language media ${ }^{3}$ and ethnic media. ${ }^{4}$ However, the increasing attention given to culture has not gone hand in hand with an overall clarification of the concept itself. Defining culture remains a difficult exercise, especially because of its multifaceted nature. The importance of the concept in media studies and its blurry theoretical grounds highlight the need to look back at how it has been used in studies. The present article is built around three main questions. First, it looks at how culture has been researched in media studies. Second, it examines possible limitations of these approaches. Third, it investigates ways in which a critical intercultural communication framework can be beneficial to media studies dealing with culture. For this purpose, this study explores recent academic discourse on media and culture by reviewing studies dealing with issues of cultural diversity, representations of culture, and discourse of culture. In addition to examining approaches to culture and their potential limitations, this article also presents ways in which critical intercultural communication can be used by researchers from different disciplines interested in culture.

2 This article starts by presenting some of the main arguments raised in discussing the use and conceptualization of culture. The way critical intercultural communication contributes to this discussion is presented, followed by reasons why it can be a relevant framework for media studies. This article then looks at previous reviews of academic discourse, especially focusing on the fields of communication and media. Methods for collecting data are detailed before discussing the findings and main implications of this study. 


\section{The Concept of Culture}

3 Culture is a concept that has been discussed extensively, giving rise to multiple approaches and uses of the term across fields of study. As the concept of culture became increasingly important and pervasive, it also became increasingly questioned. Across different fields of studies, scholars discuss whether to keep, change or altogether discard the concept of culture. Brightman brought together some of the main criticisms addressed to culture. ${ }^{5}$ His work reveals the variety of arguments used against the concept and the lack of convergence on how to revise it or what to use instead. Sewell also goes through some of the cornerstone issues in conceptualizing culture. ${ }^{6}$ The first distinction he mentions, and which he argues is not always explicitly made by researchers, is the one between the use of culture and cultures. The singular use refers to the theoretical approach used for research while the plural use refers to the object of study. Culture is used in contrast to other academic disciplines or analytical tools (e.g. politics, economics) whereas cultures is used when examining different forms of culture and is therefore more concrete (e.g. regional culture, hipster culture). Another distinction which has had a strong impact on the study of culture is the understanding of culture as practice or culture as a system of symbols and meanings. Critical intercultural scholars regard culture as a discursive construction, emphasizing the role played by individuals in performing culture. Inherited from constructionism, this approach emphasizes culture as something people do rather than something people have. ${ }^{7}$ Regarding culture as practice is the dominant approach in critical intercultural communication, which tends to be used in opposition to culture as a system of symbols and meanings. This latter approach to culture is often associated with essentialist and positivist views that describe culture as an identifiable and fixed item. ${ }^{8}$ Essentialist views of culture have been criticized for pinpointing aspects of cultures (typically reduced to the idea of national cultures) and presenting such characteristics as truths rather than constructions. ${ }^{9}$ On the other hand, critical intercultural scholars argue for an approach to culture that is largely embedded within social constructionism. ${ }^{10}$ Such an approach emphasizes culture as constructed, political, intertwined with ethics ${ }^{11}$ and related to power both within and between societies. ${ }^{12}$ From that perspective, culture is understood to be situated rather than objective, and ever changing as opposed to stable.

4 As Hall stresses, culture is about meaning and as such "permeates all of society." ${ }^{13}$ Representations, practices, values and identities have cultural meanings that are discursively constructed and tap into previous cultural discourses to be meaningful. Critical intercultural communication casts light on ways in which meanings echo cultural knowledge and are therefore difficult to identify and question - even for researchers themselves, hence a strong emphasis placed on reflexivity. ${ }^{14}$ The importance of "cultural resonance" has also been pointed out by scholars examining media frames..$^{15}$ Rivenburgh stresses the way "media frames that reflect cultural common sense, values, or ideology are both instinctually employed by journalists and easily accepted by the public". ${ }^{16}$ Tapping into cultural resonance may be done consciously or out of habit by journalists and editors who see their cultural environment as natural. The use of culturally resonant frames in media discourse increases their taken-for-grantedness, which enhances their power. Cultural markers create a sense of common sense because of their presence in everyday life experiences 
which contributes to normalizing them, making them "well-nigh impossible to recognize, question, or resist". ${ }^{17}$ The emphasis that critical intercultural communication puts on culture as having the propensity to normalize representations and practices thus appears especially relevant to media studies.

5 Another aspect where interests of both disciplines meet is the extent to which discursive practices can be ethnocentric. To different extents, critical scholars agree on the idea that discourses construct the way societies represent themselves. ${ }^{18}$ Media discourse is probably one of the discursive practices most often cited as constitutive of people's worldviews, representations of themselves and others. One question put forward by critical intercultural communication is the extent to which such discourses rely on ethnocentric representations. Ethnocentrism refers to people's tendency to use the standards of their own culture to judge other cultural groups, which is concurrent with people's tendency to regard their culture as superior to others. ${ }^{19}$ Ethnocentrism thus refers to the way cultural standards can pass as implicit norms for people identifying with that culture. As much emphasis is now put on ethnic media, cultural diversity and the effects of globalization on developing transnational media spaces, it is important not to overlook the extent to which national media discourse can still be limited and convey ethnocentric representations. The emphasis put on ethnocentrism in media has strong practical implications for professionals and audiences by encouraging them to be more critical towards news content.

\section{Examining Academic Discourse}

6 Conferences and publications are the main venues for academics to discuss the latest developments and findings from all disciplines. Nowadays, academic debate mostly takes place in journals, whose number has kept on increasing throughout the last decades. ${ }^{20}$ It is through these journals that most ideas are expressed, hence the importance of examining their content. Publishing is central for scholars, not only as a way of contributing to the development of their fields of study but also to the development of their career. The notorious "publish or perish" phrase provides an efficient summary of what publications nowadays represent in the academic world. ${ }^{21} \mathrm{As}$ journal articles have become the main venue for academic discourse, they have also turned into common and natural venues. Such development can be problematic if academic discourse comes to be granted too much legitimacy instead of having its status, form and content constantly challenged. Like other discursive practices, journal articles create and validate certain meanings that progressively become the norm and can, as such, easily pass as natural instead of constructed and contingent. ${ }^{22}$ Knowledge expressed in academic discourse is therefore not objective but is, like any other form of knowledge, "'situated' - that is, produced by and for particular interests, in particular circumstances, at particular times". ${ }^{23}$ Reflexivity, a central ethical component of research, is therefore especially important when looking at academic discourse as a whole.

7 Recently, increasing attention has been paid to cultural bias in academic discourse. Some scholars especially criticize the general lack of attention paid to such bias. Gordon, for instance, has looked at communication theories, which he describes as an example of a Western-oriented or Eurocentric approach to research. ${ }^{24}$ Gordon highlights the way communication theories have typically been elaborated by 
Caucasian researchers from the United States who mostly used university students as participants. Western-oriented theories have been criticized for being taken as universally valid despite being anchored in European academic traditions, especially the heritage of the Enlightenment period. In response, some scholars have suggested using different approaches. Asante has, for instance, put forth Afrocentricity as an ideological and methodological approach to conduct research from an African standpoint. ${ }^{25}$ Similarly, Miike encourages using Asiacentricity to examine Asian contexts from an Asian perspective. ${ }^{26}$ Miike details ways in which the concept of "communication" is defined differently by Asiacentric and Eurocentric approaches, as different aspects and outcomes are emphasized. ${ }^{27}$ Afrocentricity and Asiacentricity illustrate ongoing efforts to diversify analytical tools that would help research human activity and capture its plurality. These approaches are meant to open up new perspectives in research by providing scholars with different outlooks on their objects of study. For some scholars, developing new approaches is also meant to create legitimate alternatives to Western theories. Back in 1983, Asante, for instance, pointed out the difficulty for some African scholars to be published in Eurocentric journals because of their different, and non-valued, academic tradition. ${ }^{28}$ Shi-Xu advocates the emergence of various academic paradigms that would work "as equal but distinctive interlocutors" and help "redress this cultural imbalance". ${ }^{29}$ However, other voices among academics are more reserved when it comes to developing culture-specific approaches, fearing that it will only turn the problem around instead of solving it. Chang, Holt and Luo raise the question as they discuss Asiacentricity: "If every version of a cultural writing of other is at the same time also the construction of self, might our call for an Asiacentric perspective in explaining communication not fall into the same trap as the often-blamed Eurocentric perspective? Might the reversal of the situation prioritizing Asians - encounter the same predicament?" ${ }^{30}$ Supporters of culture-specific approaches, however, embrace this criticism. From their perspective, culture-specific approaches are beneficial because they are explicitly situated and do not try to reach universal validity. They point out that it is not so much Western-oriented theories being biased and situated that triggered critics as the lack of reflexivity about these limitations.$^{31}$ Similar debates are also taking place among media scholars, with issues of "de-Westernizing" media studies being increasingly discussed. ${ }^{32}$ Critics claim that Western-oriented media theories are too limited as they are based on European and North American political, economic and media models. Looking specifically at China, Ma argues for a compromise. ${ }^{33} \mathrm{He}$ questions the benefits of new theories that would risk "essentializing and exoticizing the Asian experience" and proposes adjusting existing theories to fit the Chinese context.

\section{Methods and Results}

8 A literature review was conducted in fall 2013 using the academic search engines EBSCO and Web of Science. The keywords "media representation", "media discourse", "diversity", and "cultur*" (the asterisk was used to include other possible endings in the data search) were used to collect peer-reviewed articles published in English between 2003 and 2013. Only articles dealing with issues of cultural diversity and media were included. Some articles in which culture was understood from an agricultural perspective were, for instance, left out. The search was ended once saturation was reached, that is when the same keywords used in different search engines brought up 
the same articles. In total, 114 articles were collected and reviewed for the purpose of this study. The literature review was conducted inductively and kept as open as possible. The search was not limited to any specific journals because the scope of topics covered by media studies on cultural diversity was expected to be very wide. One aim of this literature review being to see what types of issues were encompassed, it would have been detrimental to limit the search to certain journals.

Short descriptions were written about each article to describe their content, which later helped identify recurrent themes, similar approaches and unusual topics. Articles were collected within a 10-year time frame in order to get an overall picture of the state of recent research. No particular evolution or trends were noticed, however, regarding approaches or topics tackled. Oftentimes, authors used eclectic theoretical and/or methodological approaches that, for instance, combined cultural studies and critical discourse analysis (CDA) or feminist theories and CDA. Among studies that explicitly presented their theoretical and/or methodological frameworks, CDA (9\%), feminist theories (10\%) and cultural/critical frameworks relying on Foucault's, Gramsci's or Hall's theories (29\%) were recurrent approaches. As regards analytical tools from journalism or media studies, results indicated that framing theory (10\%) was often used as opposed to gatekeeping or agenda-setting theory (2\%). Similarly to results from previous reviews of academic discourse,$^{34}$ studies from this data set appeared to be mainly conducted from a Western-oriented perspective. This was the case even for strongly situated studies that focused on particular cultures and were published in specific journals. For instance, the article "Media Representations of the South African Truth and Reconciliation Commission and Their Commitment to Reconciliation" ${ }^{35}$ was published in the Journal of African Cultural Studies using CDA, and the article "The Representation of Cultural Diversity in Urdu-Language Newspapers in Pakistan: A Study of Jang and Nawaiwaqt" ${ }^{36}$ was published in the South Asia Journal of South Asian Studies and used Hodder's approach. In comparison, articles looking at representations of women were found to use various trends of feminist theories such as standpoint theory, ${ }^{37}$ postcolonial theory ${ }^{38}$ and black feminism. ${ }^{39}$ Similarly, articles explicitly dealing with race, for instance, used postcolonial theory ${ }^{40}$ and Jackson's (2006) theory of scripting and media framing of black bodies. ${ }^{41}$

10 As regards the scope of topics tackled, results indicated that the majority of articles investigated representation of minorities in the media (67\%), most often dealing with ethnic or religious groups. Articles within this category oftentimes raised the issue of media stereotyping and othering minorities. That is, studies investigated ways in which media discourse sometimes supports the construction of minorities as "Others", which can emphasize differences between groups and convey negative stereotypical representations..$^{42}$ Among articles exploring representations of minorities, several studies dealt with sport and representations of athletes (8\%). A significant number of studies examined discourses of diversity (23\%), with some focusing exclusively on European discourses of diversity (3\%). Other studies investigated what diversity stands for in the media and how it can be approached by newsrooms. On the other hand, some topics appeared to be scarcely tackled, which was the case of foreign-news coverage (4\%), newsroom diversity (2\%) or integration and acculturation issues (2\%). Regarding the type of media investigated, the majority of studies examined newspapers and television (70\%), while entertainment and advertisement (19\%) were less considered. 


\section{Culture: Between Main Focus and Transparent Background}

11 Despite explicitly dealing with culture, many articles did not provide a clear definition of the term. Nor did many researchers position themselves as regards the different schools of thought on culture. Instances of culture taken for granted particularly occurred in the literature when (1) culture was associated with nations or (2) the socalled Western world, or (3) when the concepts of race or ethnicity were used.

Results from the literature review conducted for this study indicate the recurrent association of culture with that of nation. However, the use of countries as cultural contexts and embodiments of cultures can be problematic for several reasons. A main pitfall is the homogeneous and reduced picture of culture that it conveys. Culture is a multilayered notion and reducing it to the single aspect of nationality can be detrimental to both the idea of nation and culture. Nations are multicultural, in the literal meaning of the word: that is, made out of multiple cultures. Studies that use nation as the unit of reference to talk about culture, language and identity tend to homogenize national cultures and therefore increase chances of being stereotypical instead of deconstructing stereotypes. A second important drawback is the way national culture tends to be presented as normal instead of artificial. This contributes to discourses of "banal nationalism" where individuals are brought up with the idea that the world is divided between nations. ${ }^{43}$ It also overlooks the fact that culture is constructed and thus intertwined with power and struggle. When culture is understood as the equivalent of nation, it typically hints at the culture of the dominant group within that nation. Such representation leaves out or even marginalizes other forms of culture within that country, therefore maintaining existing hierarchy instead of deconstructing it. Halualani, Mendoza and Drzewiecka point out the danger of blurring the lines between the concepts of culture and nation: "To accept cultures as nations as inherently and naturally truthful and accurate at a surface level would be to risk reproducing external framings of cultural groups advanced by colonialist governments, dominant nationalist parties, and ruling power interests that benefit from such 'status quo' thinking." ${ }^{44}$

Associating culture to nation thus tends to sustain hierarchy between cultural practices and those who practice or identify to them. By maintaining hierarchical order between cultures, the nation approach implicitly contributes to preserving the persistent dichotomy between "us" and "them", whether within or between nations. The nation approach to culture is tightly related to essentialist views of culture in that it provides a static and homogeneous picture of culture. Essentialism regards culture as a onedimensional concept and therefore leaves out issues of race, religion, gender, social status and larger historical and political structures. Critical intercultural communication endeavors to go beyond such limitations by taking into account the multidimensional, constructed, contingent and dynamic facets of culture. The critical intercultural communication approach does not dismiss nations as possible instances of cultures. However, it focuses on exploring which representations of culture and nation are associated, through which processes, and whether such associations vary in time or depending on the context. Critical intercultural scholars emphasize culture as raising questions rather than providing answers that would help predict people's behaviors. ${ }^{45}$ Through its conceptualization of culture, a critical intercultural communication 
framework helps focus on ways in which people construct their sense of cultural belonging and identity ${ }^{46}$ This approach is relevant to media studies in many ways. It is strongly related to research exploring the relation individuals make between their media consumption and their identity, or research dealing with the way media discourse is intertwined with discourses of (national) identity. The emphasis put on constructing cultural identity and belonging can also help focus on who is represented as "belonging" and who is not, which is a significant aspect of studies on minority media and cultural diversity.

As mentioned beforehand, results indicated that culture can be taken for granted when it is about "us". In many cases, "our" culture is used as a background for research, making it look normal and neutral. "Our" culture also appears homogeneous because examining diversity oftentimes consists of examining the "Other". For instance, the article entitled "Comparative Analysis of Mainstream Discourses, Media Narratives and Representations of Islam in Britain and France Prior to 9/11" examines the construction of Islam, notably referring to the switch from exoticism before $9 / 11$ to terrorism afterwards. ${ }^{47}$ The article, however, does not discuss the construction of "British" and "French" but uses them as taken-for-granted cultural representations. Similarly, the article "The Construction of the Image of Immigrants and Ethnic Minorities in two Portuguese Daily Newspapers" discusses the way "their" image is fabricated and thus artificial but does not discuss the construction of the "Portuguese" identity. ${ }^{48}$ Of course, focusing on minorities' identities is highly relevant, but it could be beneficial to consider both majorities' and minorities' identities and cultures. Such an approach could help examine diversity among "us" rather than embodied only by "them". Examining both majority and minority could enable researchers to go beyond this dichotomous opposition and not only look at differences but also cast light on shared cultural representations, practices or identities. Looking at differences and similarities, as well as how those are negotiated, can also help examine the way cultural meanings and identities are constructed in relation to one another. Overall, it would be a way to put all cultural practices and representations on an equal footing by explicitly defining them as constructed and contingent. This could in turn contribute to challenge taken-for-granted perceptions we have of ourselves as well as of others.

Findings also indicate that the concept of culture tends to be used in different ways depending on whose culture is examined. The "us" is often associated with nationality and presented as legitimate, neutral, acultural, aethnical and aracial while the "them" is often referred to in terms of religious or ethnic denominations. Oftentimes, culture is not directly problematized when the concepts of race and ethnicity are used. Eventually, this paints a picture where "we" seem to be acultural and unproblematic while "they" are described in terms of struggle, race, ethnicity or religious affiliations. The imbalance in such representations is problematic in that it reproduces stereotypical representations of minorities even though most studies intend to deconstruct them. Using alternatives to Western and Eurocentric approaches in media studies could help dismiss such a vicious circle. Enhancing geographical diversity as regards research location could also encourage study of various minority groups. Indeed, findings suggest that numerous studies are located in Europe, North America or Australia: parts of the world that embody the idea of "Western culture". The lack of diversity in the location of research is a strong shortcoming of academic discourse, especially when it examines representation of minorities. Going through numerous articles dealing with ethnic or religious minorities living in the so-called Western world 
nourishes the idea that majority and dominant groups are white Europeans while struggling minorities are black, Asians or Muslims. Using a critical intercultural communication framework can discourage researchers from using or describing, even implicitly, certain groups or practices as acultural and neutral and others as only racial or ethnic. This issue has also been raised by scholars working on colorblind ideology. Browne, for instance, argues that in both the United States and France, being white is "the invisible norm against which all other cultural and racial groups are defined and subordinated" ${ }^{49}$ The notion of invisible norm raised by Browne is particularly relevant when it comes to seeing oneself as aracial or acultural and seeing others mostly through their skin color, religious affiliations or cultural practices. The way concepts of race and ethnicity can sometimes be used instead of the one of culture conveys the idea that they refer to different aspects. Nevertheless, race and ethnicity are forms of culture, as gender, nationality or social class can also be. Dismissing culture and using only race and ethnicity can be a drawback in that it contributes to presenting culture as unproblematic and natural, while race and ethnicity are sources of struggle. Using a critical intercultural communication framework is a way to be inclusive and critically tackle all aspects of culture. Bridging the gap between culture, race and ethnicity is also a way to bring together schools of thought (for instance, scholars from the United States and scholars from Europe) that have different stances on the concept of race itself. Examining critically the way race, ethnicity, social status, religious, sexual and gender identities are constructed and conveyed can thus enrich our understanding of culture. Generally speaking, using a critical approach to the concept of culture would help address problematic representations of minority/majority and us/them in academic discourse. Understanding culture as a construction that involves power relations and struggle contributes to include every individual, group and practice, since all aspects and members of societies are cultural. This therefore takes away the pervasive and implicit idea that some people or practices are neutral to some extent. Reflexivity is a central component in order to be able to detach oneself from ethnocentric representations and look at oneself, one's culture, practices and values as cultural and therefore constructed and ideological. Focusing on cultural identity as constructed is also an asset in decreasing ethnocentrism or cultural bias in academic discourse. Encouraging researchers to be reflexive about their cultural backgrounds can help them problematize what they could otherwise take for granted about their own cultural identities and belongings. As Rorty points out, no one is ahistorical or acultural and therefore "everybody is ethnocentric when engaged in actual debate". ${ }^{50}$ The best way to overcome ethnocentric representations is to make them and the way they are constructed salient. Ethnocentrism in academic discourse is particularly problematic because research aims at being, if not entirely unbiased, at least critical towards its inherent subjectivity. Ethnocentrism as a form of bias is difficult to overcome if not addressed directly. Researchers should therefore aim at being critical towards their personal background as well as their philosophical, theoretical and methodological heritage. Cultural baggage has to be reflected upon at the individual level, that is, in the way personal choices affect the way researchers tackle a topic or analyze data, but also at the academic level, that is, the way they can be blind to the overall schools of thought to which they belong. 


\section{Conclusion}

The concept of culture is regarded by many as ambiguous, difficult to conceptualize, and even non-operational by some scholars. In spite of its difficult reputation, culture remains a prominent object of study. Influences from critical theories and social constructionism make critical intercultural communication a relevant framework for examining representations and discursive constructions of culture. The premise that culture is constructed provides a solid ground to examine ways in which certain representations seem more powerful or natural than others. It also emphasizes the fact that we live in webs of cultural discourses - some invisible to us, depending on contexts - that are intertwined with other discourses. The main aim of using a critical intercultural communication framework is not to uncover what culture really is but to uncover what representations of culture come to appear real, and through which processes. Studies therefore primarily focus on the way we navigate these webs and make sense of them, the way they are constructed, interrelated and empowered. The main asset of this framework is its emphasis on problematizing culture, which reduces risks of taking it for granted. As such, critical intercultural communication also encourages researchers to be reflexive about their academic and cultural background. This can help one be aware of the extent to which one's knowledge is situated, and therefore contributes to decreasing cultural bias in academic discourse. Generally, being aware of the representations we have of ourselves and others, as well as the reasons why these representations are constructed and conveyed, is central to developing understanding and tolerance towards others. This is especially relevant now that more and more people cross borders and that communication between cultures is faster, easier, and therefore increasingly common.

\section{BIBLIOGRAPHY}

Asante, Molefi Kete. “The Ideological Significance of Afrocentricity in Intercultural

Communication." Journal of Black Studies 14(1) (1983): 3-19.

-. Afrocentricity: The Theory of Social Change. Chicago: African American Images, 2003.

Barker, Chris. The SAGE Dictionary of Cultural Studies. London: SAGE Publications, 2004. DOI: http:// dx.doi.org/10.4135/9781446221280.

Billig, Michael. Banal Nationalism. London: Sage Publications, 1995.

Bredström, Anna. "Gendered Racism and the Production of Cultural Difference: Media Representations and Identity Work among 'Immigrant Youth' in Contemporary Sweden." Nora: Nordic Journal of Women's Studies 11(2) (2003): 78-88.

Brightman, Robert. "Forget Culture: Replacement, Transcendence, Relexification." Cultural Anthropology 10(4) (1995): 509-546. 
Brown, Malcolm D. “Comparative Analysis of Mainstream Discourses, Media Narratives and Representations of Islam in Britain and France Prior to 9/11." Journal of Muslim Minority Affairs 26(3) (2006): 297-312.

Browne, Anthony. "Denying Race in the American and French Context." Wadabagei 10(1) (2009): 73-91.

Carvalho, Margarida. "The Construction of the Image of Immigrants and Ethnic Minorities in Two Portuguese Daily Newspapers." Portuguese Journal of Social Science 9(2) (2010): 165-176.

Chang, Hui-Ching, Rich Holt, and Lina Luo. "Representing East Asians in Intercultural Communication Textbooks: A Select Review." The Review of Communication 6(4) (2006): 312-328.

Curran, James and Myung-Jin Park. "Beyond Globalization Theory." In De-Westernizing Media Studies, edited by James Curran and Myung-Jin Park, 3-18. London: Routledge, 2000.

Darling-Wolf, Fabienne. "Sites of Attractiveness: Japanese Women and Westernized Representations of Feminine Beauty." Critical Studies in Media Communication 21(4) (2004): 325-345.

Dervin, Fred. “Approches dialogiques et énonciatives de l'interculturel : pour une didactique des langues et de l'identité mouvante des sujets." Synergies Roumanie 4 (2009): 165-178.

-. "A Plea for Change in Research on Intercultural Discourses: A 'Liquid' Approach to the Study of the Acculturation of Chinese Students." Journal of Multicultural Discourses 6(1) (2011): 37-52.

Entman, Robert M. "Framing Bias: Media in the Distribution of Power." Journal of Communication 57(1) (2007): 163-173.

Erickson, Keith V., Cathy A. Fleuriet, and Lawrence A. Hosman. "Prolific Publishing: Professional and Administrative Concerns." Southern Journal of Communication 58(4) (1993): 328-338.

Gamson, William A., and Andre Modigliani. "Media Discourse and Public Opinion on Nuclear Power: A Constructionist Approach." American Journal of Sociology 95(1) (1989): 1-37.

Gordon, Ronald D. "Beyond the Failures of Western Communication Theory." Journal of Multicultural Discourses 2(2) (2007): 89-107.

Hall, Stuart. "Introduction.” In Representation: Cultural Representations and Signifying Practices, edited by Stuart Hall, 1-12. London: Sage Publications, 1997.

Halualani, Rona Tamiko, S. Lily Mendoza, and Jolanta A. Drzewiecka. “'Critical' Junctures in Intercultural Communication Studies: A Review.” The Review of Communication 9,(1) (2009): 17-35.

Jiwani, Yasmin. "War Talk Engendering Terror: Race, Gender and Representation in Canadian Print Media." International Journal of Media \& Cultural Politics 1(1) (2005): 15-22.

Jørgensen, Marianne and Louise J. Phillips. Discourse Analysis as Theory and Method. London: Sage Publications, 2002.

Kramer, Michael W., Jon A. Hess, and Loren D. Reid. "Trends in Communication Scholarship: An Analysis of Four Representative NCA and ICA Journals over the Last 70 Years." The Review of Communication 7(3) (2007): 229-240.

Kubota, Ryuko. "Critical Approaches to Intercultural Discourse and Communication." In The Handbook of Intercultural Discourse and Communication, edited by Christina Bratt Paulston, Scott F. Kiesling, and Elizabeth S. Rangel, 90-109. Malden, MA: John Wiley \& Sons, 2012.

Ma, Eric Kit-Wai. "Rethinking Media Studies: The Case of China." In De-westernizing Media Studies, edited by James Curran and Myung-Jin Park, 17-28. London: Routledge, 1994. 
MacLure, Maggie. Discourses in Educational and Social Research. Buckingham: Open University Press, 2003.

Merskin, Debra L. Media, Minorities, and Meaning: A Critical Introduction. New York: Peter Lang, 2011.

Miike, Yoshitaka. "Non-Western Theory in Western Research? An Asiacentric Agenda for Asian Communication Studies." The Review of Communication 6(1-2) (2006): 4-31.

-. "An Asiacentric Reflection on Eurocentric Bias in Communication Theory." Communication Monographs 74(2) (2007): 272-278.

Olausson, Ulrika. "Global warming - Global Responsibility? Media Frames of Collective Action and Scientific Certainty." Public Understanding of Science 18(4) (2009): 421-436.

Pietikäinen, Sari, and Hellen Kelly-Holmes. "The Dangers of Normativity - The Case of Minority Language Media." In Dangerous Multilingualism: Northern Perspectives on Order, Purity and Normality, edited by Jan Blommaert et al., 194-204. Basingstoke, UK: Palgrave Macmillan, 2012.

Piller, Ingrid. Intercultural Communication: A Critical Introduction. Edinburgh: Edinburgh University Press, 2011.

Poirier, Sylvie. "La (dé)politisation de la culture ? Réflexions sur un concept pluriel." Anthropologie et sociétés 28(1) (2004): 7-21.

Reid-Brinkley, Shanara Rose. "Ghetto Kids Gone Good: Race, Representation, and Authority in the Scripting of Inner-City Youths in the Urban Debate League." Argumentation \& Advocacy 49(2) (2012): 77-99.

Rigoni, Isabelle. "Intersectionality and Mediated Cultural Production in a Globalized PostColonial World." Ethnic and Racial Studies 35(5) (2012): 834-849.

Rivenburgh, Nancy K. "Media Framing of Complex Issues: The Case of Endangered Languages." Public Understanding of Science 22(6) (2013): 704-717.

Rorty, Richard. "Solidarity or Objectivity." In Knowledge and Inquiry. Readings in Epistemology, edited by K. Brad Wray, 422-437. Peterborough, ON, Canada: Broadview Press, 2002.

Sewell Jr, William H. “The Concept (s) of Culture." In Practicing History: New Directions in Historical Writing After the Linguistic Turn, edited by Gabrielle M. Spiegel, 76-95. New York: Routledge, 2005.

Shi-Xu. A Cultural Approach to Discourse. New York: Palgrave Macmillan, 2005.

-. "Reconstructing Eastern Paradigms of Discourse Studies." Journal of Multicultural Discourses 4(1) (2009): 29-48.

Shohat, Ella, and Robert Stam. Unthinking Eurocentrism. Multiculturalism and the Media. New York: Routledge, 1994.

Soares, Maria Andrea Dos Santos. "Look, Blackness in Brazil!: Disrupting the Grotesquerie of Racial Representation in Brazilian Visual Culture.” Cultural Dynamics 24(1) (2012): 75-101.

Storey, John. What is Cultural Studies? A Reader. London: Arnold, 1996.

Syed, Jawad. "The Representation of Cultural Diversity in Urdu-Language Newspapers in Pakistan: A Study of Jang and Nawaiwaqt." South Asia: Journal of South Asian Studies 31(2) (2008): 317-347.

Verdoolaege, Annelies. "Media Representations of the South African Truth and Reconciliation Commission and their Commitment to Reconciliation." Journal of African Cultural Studies 17(2) (2005): 181-199. 
Woodward, Kathryn ed., Identity and Difference. London: Sage Publications, 1997.

\section{ENDNOTES}

1. Debra L. Merskin, Media, Minorities, and Meaning: A Critical Introduction (New York: Peter Lang Publishing, 2011).

2. Robert M. Entman, "Framing Bias: Media in the Distribution of Power," Journal of Communication 57, (2007).

3. Sari Pietikäinen and Helen Kelly-Holmes, "The Dangers of Normativity - The Case of Minority Language Media," in Dangerous Multilingualism: Northern Perspectives on Order, Purity And Normality, ed. Jan Blommaert et al. (Houndmills, Basingstoke: Palgrave Macmillan, 2012), 194-204.

4. Isabelle Rigoni, "Intersectionality and Mediated Cultural Production in A Globalized PostColonial World," Ethnic and Racial Studies 35 (2012).

5. Robert Brightman, "Forget Culture: Replacement, Transcendence, Relexification," Cultural Anthropology 10, (1995).

6. William H. Sewell Jr, "The Concept(s) of Culture," in Practicing History: New Directions in Historical Writing after the Linguistic Turn, ed. Gabrielle M. Spiegel (New York: Routledge, 2005), 76-95.

7. Ingrid Piller, Intercultural Communication: A Critical Introduction (Edinburgh: Edinburgh University Press, 2011), 15.

8. Ibid.

9. Fred Dervin, “Approches dialogiques et énonciatives de l'interculturel : Pour une didactique des langues et de l'identité mouvante des sujets," Synergies Roumanie 4 (2009): 166-167.

10. Fred Dervin, "A Plea for Change in Research on Intercultural Discourses: A "Liquid" Approach to the Study of the Acculturation of Chinese Students," Journal of Multicultural Discourses 6 (March 2011): 38 .

11. Sylvie Poirier, "La (dé)politisation de la culture? Réflexions sur un concept pluriel," Anthropologie et sociétés 28 (2004): 10-13.

12. Ryuko Kubota, "Critical Approaches to Intercultural Discourse and Communication," in The Handbook of Intercultural Discourse and Communication, ed. Christina Bratt Paulston et al. (Malden, USA: John Wiley \& Sons, 2012), 95.

13. Stuart Hall, "Introduction," in Representation: Cultural Representations and Signifying Practices, ed. Stuart Hall (London: Sage Publications, 1997), 3.

14. Shi-Xu, A Cultural Approach to Discourse (New York: Palgrave Macmillan, 2005), 1-13.

15. William A. Gamson and Andre Modigliani, "Media discourse and Public Opinion on Nuclear Power: A Constructionist Approach," American Journal of Sociology 95 (1989): 5.

16. Nancy K. Rivenburgh, "Media Framing of Complex Issues: The Case of Endangered Languages," Public Understanding of Science 22 (2011): 706.

17. Ulrika Olausson, "Global warming - Global Responsibility? Media Frames of Collective Action and Scientific Certainty," Public Understanding of Science 18 (2009): 423.

18. Marianne Jørgensen and Louise J. Phillips, Discourse Analysis as Theory and Method (London: Sage Publications, 2002), 175-177.

19. Chris Barker, The Sage Dictionary of Cultural Studies (London: Sage Publications, 2004), 64-65.

20. Keith V. Erickson, Cathy A. Fleuriet and Lawrence A. Hosman, "Prolific Publishing: Professional and Administrative Concerns," The Southern Communication Journal 58 (Summer 1993): 328-329.

21. Michael W. Kramer, Jon A. Hess and Loren D. Reid, "Trends in Communication Scholarship: An Analysis of Four Representative NCA and ICA Journals over the Last 70 Years," The Review of Communication 7 (July 2007): 229-230. 
22. Jørgensen and Phillips, Discourse Analysis as Theory and Method, 175-177.

23. Maggie MacLure, Discourses in Educational and Social Research (Buckingham: Open University Press, 2003), 175.

24. Ronald D. Gordon, "Beyond the Failures of Western Communication Theory," Journal of Multicultural Discourse 2 (2007).

25. Molefi Kete Asante, "The Ideological Significance of Afrocentricity in Intercultural Communication," Journal of Black Studies 14 (1983).

26. Yoshitaka Miike, "Non-Western Theory in Western research? An Asiacentric Agenda for Asian Communication Studies," The Review of Communication 6, (2006).

27. Yoshitaka Miike, "An Asiacentric Reflection on Eurocentric Bias in Communication Theory," Communication Monographs 74 (2007).

28. Asante, "The Ideological Significance of Afrocentricity in Intercultural Communication," 10.

29. Shi-Xu, "Reconstructing Eastern Paradigms of Discourse Studies," Journal of Multicultural Discourses 4 (2009): 33.

30. Hui-Ching Chang, Rich Holt and Lina Luo, "Representing East Asians in Intercultural Communication Textbooks: A Select Review," The Review of Communication 6 (2006): 325-326.

31. Molefi Kete Asante, Afrocentricity: The Theory of Social Change (Chicago: African American Images, 2003), 61.

32. Ella Shohat and Robert Stam, Unthinking Eurocentrism: Multiculturalism and the Media (London: Routledge, 1994); James Curran and Myung-Jin Park, De-westernizing Media Studies (London: Routledge, 2000).

33. Eric Kit-Wai Ma, "Rethinking Media Studies: The Case of China," in De-westernizing Media Studies, ed. James Curran et al. (London: Routledge, 1994), 32.

34. See for example Gordon, "Beyond the Failures of Western Communication Theory," and Miike, "An Asiacentric Reflection on Eurocentric Bias in Communication Theory".

35. Annelies Verdoolaege, "Media representations of the South African Truth and Reconciliation Commission and their Commitment to Reconciliation," Journal of African Cultural Studies 17 (2005).

36. Jawad Syed, "The Representation of Cultural Diversity in Urdu-Language Newspapers in Pakistan: A Study Of Jang And Nawaiwaqt," Journal of South Asian Studies 31 (2008).

37. Yasmin Jiwani, "War Talk Engendering Terror: Race, Gender and Representation in Canadian Print Media," International Journal of Media \& Cultural Politics 1 (2005).

38. Fabienne Darling-Wolf, "Sites of Attractiveness: Japanese Women and Westernized Representations of Feminine Beauty," Critical Studies in Media Communication 21 (2004).

39. Maria Andrea Dos Santos Soares, "Look, Blackness in Brazil!: Disrupting the Grotesquerie of Racial Representation in Brazilian Visual Culture," Cultural Dynamics 24 (2012).

40. Anna Bredström, "Gendered Racism and the Production of Cultural Difference: Media Representations and Identity Work among 'Immigrant Youth' In Contemporary Sweden," Nora: Nordic Journal of Women's Studies 11 (2003).

41. Shanara Rose Reid-Brinkley, "Ghetto Kids Gone Good: Race, Representation, and Authority in the Scripting of Inner-City Youths in the Urban Debate League," Argumentation \& Advocacy 49 (2012).

42. Kathryn Woodward, Identity and Difference (London: Sage Publications, 1997), 35.

43. Michael Billig, Banal Nationalism (London: Sage Publications, 1995), 6.

44. Rona T. Halualani, S. Lily Mendoza and Jolanta A. Drzewiecka, “'Critical”" Junctures in Intercultural Communication Studies: A Review," The Review of Communication 9 (January 2009):

24.

45. Piller, Intercultural Communication: A Critical Introduction, 66-69.

46. Dervin, “A Plea For Change in Research on Intercultural Discourses," 41. 
47. Malcom D. Brown, "Comparative Analysis of Mainstream Discourses, Media Narratives and Representations of Islam in Britain and France Prior to 9/11," Journal of Muslim Minority Affairs 26 (2006).

48. Margarida Carvalho, "The Construction of the Image of Immigrants and Ethnic Minorities in Two Portuguese Daily Newspapers," Portuguese Journal of Social Science 9 (2010).

49. Anthony P. Browne, "Denying Race in the American and French Context," Wadabagei 12 (2009): 83.

Richard Rorty, "Solidarity or Objectivity," in Knowledge and Inquiry. Readings in Epistemology, ed. K. Brad Wray (Peterborough, ON: Broadview Press, 2002), 432.

50.

\section{ABSTRACTS}

This study examines the way culture has been researched in media studies and suggests how critical intercultural communication could contribute to the field. A literature review was conducted and articles ( $\mathrm{N}=114)$ published in peer-reviewed journals between 2003 and 2013 were collected. Results show that studies dealing with media and culture do not systematically define the concept of culture. Findings also indicate that culture is oftentimes taken for granted instead of being problematized and addressed as a source of struggle. Advantages of using a critical intercultural communication framework to examine culture are discussed.

INDEX

Keywords: critical intercultural communication, media studies, culture, academic discourse, critical/cultural studies

\section{AUTHOR}

\section{MÉLODINE SOMMIER}

Mélodine Sommier is a doctoral student in intercultural communication at the University of Jyväskylä in Finland. She has particular interests in migration and acculturation issues as well as discourses of culture in the media. 